IJOTL $\sim$ TL, Vol. 5, No. 3, September 2020

p ISSN: 2502 2326; e ISSN: 2502 8278

Https://soloclcs.org; Email: ijolt1@gmail.com

Center of Language and Cultural Studies, Surakarta, Indonesia

Islam, Nazifa, Naushin. (2020). Implementation of Postmethod Pedagogy as an Alternative

to Communicative Language Teaching at the Tertiary Level Education.

IJOTL TL (2020), 5(3), 135 154. DOI: 10.30957/ijot1 tl.v5i3.633.

\title{
Implementation of Postmethod Pedagogy as an Alternative to Communicative Language Teaching at the Tertiary Level Education
}

\author{
Naushin Nazifa Islam, Senior Lecturer \\ Department of English, East West University, Dhaka, Bangladesh \\ Email: naushin203312@gmail.com
}

\begin{abstract}
Along with the subsequent development in the field of English Language Teaching, the idea of methods has been criticized for not being sensitive to the contextual factors and also for being imperialistic in nature. The linguistic and cultural dimensions of archetypal methods establish the culture and language of the native speakers as the only erudite variety by promoting monoculturalism and monolingualism. Furthermore, even in Bangladesh, it can be seen that CLT has been applied as a method to teach English as a foreign/second language since the mid-nineties, but it has not brought any significant changes. Therefore, to overcome the obstacles and limitations experienced by the application of the prototypical methods, the notion of postmethod pedagogy has been introduced which focuses on the significance of contextualized materials to bring authenticity in English language classrooms, which in turn ensures learners' motivation and successful intake of the lesson. At the same time, it also emphasizes the importance of teacher and learner autonomy. Hence, this research paper explores the scopes of the implementation of postmethod pedagogy and its effectiveness at the tertiary level English language classrooms in Bangladesh.
\end{abstract}

Keywords: Communicative Language Teaching (CLT), postmethod pedagogy, English Language Teaching, tertiary level, Bangladesh

\section{INTRODUCTION}

In search of a single and ideal method that can be universally applied to the learners, language teachers and practitioners have always tried to come up with new methods and principles of language teaching. In fact, this whole century has been known as the age of methods. In this incidence, the word method represents a specific design of instruction or a system which is supported by a theory of language or language learning (Richards \& Rodgers, 2001). With a similar belief, Nunan (2003) has added that it is a single set of procedures that can be followed by the teachers in their classrooms. Among all the methods, Communicative Language Teaching (CLT) reached at the peak of success as it highlights learners' communicative competence which is learners' ability to proficiently express what they mean in the target language by successfully communicating in real-life situations (Lightbown \& Spada, 1999). 
IJOTL TL, Vol. 5, No. 3, September 2020

p ISSN: 2502 2326; e ISSN: 2502 8278

Https://soloclcs.org; Email: ijolt1@gmail.com

Center of Language and Cultural Studies, Surakarta, Indonesia

Islam, Nazifa, Naushin. (2020). Implementation of Postmethod Pedagogy as an Alternative

to Communicative Language Teaching at the Tertiary Level Education.

IJOTL TL (2020), 5(3), 135 154. DOI: 10.30957/ijotl tl.v5i3.633.

However, the practitioners reached a stage where it was evident that no single method was enough for one type of classroom. No method can account for all the outcomes and contextual elements of a language classroom. Pennycook (1989) argued that methods are never 'disinterested', but serve the dominant power structures in society, leading to "a de-skilling of the role of teachers, and greater institutional control over classroom practice"'(p. 610). The demise of method gives rise to a 'post-method' era; as long ago as 1983, Stern declared that several current developments point forward a transition from the focus and application of any single method in language pedagogy to a more context-specific and autonomous teaching and learning environment. At around the same time, Kumaravadivelu (1994) identified what he termed as 'postmethod condition', which was a result of the limitations found in the pre-existing methods and dissatisfactions experienced by the teachers in different contexts.

This research paper aims at finding the possibilities and potentials of implementing postmethod pedagogy instead of CLT in language classes at the tertiary level education in Bangladesh.

\subsection{Research questions} the study.

The researcher has tried to find the answers of the following questions through

a) What are the difficulties experienced by English language teachers at the tertiary level while implementing CLT in language classes?

b) How feasible is it for teachers to attain the objectives of postmethod pedagogy at the tertiary level English language classes?

c) What are the possibilities available to students to experience the advantages of postmethod pedagogy at the tertiary level English language classes?

\section{LITERATURE REVIEW}

\subsection{Retrospective of CLT}

CLT has been the most widely accepted methodology in language teaching until the advent of postmethod pedagogy. This approach was originated to counter the shortcoming of the audio-lingual method and grammar-translation method (Richards and Rodgers, 2001). CLT can also be defined as a theoretical approach that implements a communicative view of the target language from syllabus design to classroom activities (Didenko \& Pichugova, 2016).

\subsubsection{Impairments Found in CLT in the Asian Context}

CLT has faced a lot of criticism from many researchers and teachers. Researches from many countries returned disappointing results on implementing CLT in the classrooms. Li (1998) has mentioned in his article the cultural constraints teachers experienced in introducing CLT in South Korea and also in other Asian countries, such as China, Hong Kong, Japan, Vietnam, Pakistan, Singapore and the Philippines. Moreover, in 2001, Gahin and Mayhill discussed the condition of CLT in Egypt, and they talked about two specific barriers found in the context. The first barrier includes several chal- 
IJOTL TL, Vol. 5, No. 3, September 2020

p ISSN: 2502 2326; e ISSN: 2502 8278

Https://soloclcs.org; Email: ijolt1@gmail.com Center of Language and Cultural Studies, Surakarta, Indonesia

Islam, Nazifa, Naushin. (2020). Implementation of Postmethod Pedagogy as an Alternative to Communicative Language Teaching at the Tertiary Level Education. IJOTL TL (2020), 5(3), 135 154. DOI: 10.30957/ijotl tl.v5i3.633.

lenges found in the scarcity of resources, a large number of students without adequate facilities, pressure from the institution, and supervisors etc. The second one centers on intrinsic barriers. For example, cultural factors which include reluctance among students, negative attitudes to group and pair work, and over-dependency on teachers. Moreover, Ghanbari and Ketabi blamed the pattern of University Entrance Exam (UEE) in Iran to act as a roadblock to the success of CLT. As UEE provides more importance to grammatical learning above language knowledge and communication, teachers are obliged to emphasize more on grammar, vocabulary, reading, and writing skills instead of speaking and listening skills which are crucial for communicative competencies. They also follow the grammar-translation method for teaching English in class (2011).

The cultural practices also make it difficult to implement CLT in classes as our students are not ready to take the responsibilities of their own learning. The teacher is not a facilitator here, but "the authoritarian purveyor of knowledge, one to lead and to draw matters to a correct conclusion" (Koosha and Yakhabi, 2013, p.81). Liao (2004) adds that in Asian cultural context, it is assumed that the teacher should act as the central figure who must be honored, and his/her students must passively listen to him/her without causing any interruption by asking a question or making a request for clarification. This formal relationship between teacher and student where the teacher is presumed to be a superior, omniscient figure while the students are a group of individuals who must obey and receive the teacher's explanations cannot create a communicative learning environment.

Islam (2001) and Huda (2013) have shed light on the context of Bangladesh. According to Huda, "The context of Bangladesh has its own peculiarities in terms of cultural and situational variables, which claims a specific kind of teaching-learning practices for ELT in the country" (2013, p.13). Due to the local cultural and familial orientation, Bangladeshi students tend to depend solely on their teachers for learning rather than being autonomous and innovative. Teachers are considered as an authoritative person here, and asking questions or getting into a debate is considered as a sign of disrespect; moreover, teachers in schools and colleges do not follow a communicative approach and do not appreciate the practice of students asking questions (Islam, 2000).

\subsection{Retrospective of Postmethod Pedagogy}

The unending quest for the latest and greatest method started to lose its pace when Kumaravadivelu brought forth the idea to move the target beyond methods or also known as the "postmethod era". The base of postmethod was exactly what every individual method was lacking, the ability to be a complete package of processes for any specific EFL or ESL context. Kumaravadivelu also believed that no single method or approach can be appropriate for any language teaching context. One of the clearest distinctions between the method and post method era is the focus of the construction of the relevant theories, where the method era was dominated by practitioners focusing on knowledge-oriented theories and the post method era had more classroom-oriented theories (Kumaravadivelu, 2001). 
IJOTL TL, Vol. 5, No. 3, September 2020

p ISSN: 2502 2326; e ISSN: 2502 8278

Https://soloclcs.org; Email: ijolt1@gmail.com

Center of Language and Cultural Studies, Surakarta, Indonesia

Islam, Nazifa, Naushin. (2020). Implementation of Postmethod Pedagogy as an Alternative

to Communicative Language Teaching at the Tertiary Level Education.

IJOTL TL (2020), 5(3), 135 154. DOI: 10.30957/ijot1 tl.v5i3.633.

\subsubsection{Parameters of Postmethod Pedagogy}

Kumaravadivelu $(2001,2003)$ visualized post method pedagogy as a threedimensional system with three pedagogic parameters which are particularity, practicality, and possibility.

The parameter of particularity is based on the belief that any language teaching program "must be sensitive to a particular group of teachers teaching a particular group of learners pursuing a particular set of goals within a particular institutional context embedded in a particular sociocultural milieu" (Kumaravadivelu, 2001, p.538). The idea of pedagogic particularity is related to the situational understanding which highlights the context-sensitive nature of language teaching. As a result, this kind of pedagogy is responsive to and responsible for the local, individual, institutional, social and, cultural context where the teaching and learning take place (Kumaravadivelu, 2001).

The parameter of practicality refers to the relationship between theory and practice. If context-sensitive pedagogic knowledge has to emerge from teachers and their practice of everyday teaching, then it will enable them to theorize from their practice and practice what they theorize (Kumaravadivelu, 1994; Chen, 2014). Once the teachers will be given the opportunity to theorize their ideas and perceptions based on their experiences, interest, and intuitions acquired from the language classroom, it will create the space for a "teacher-generated theory of practice" (Kumaravadivelu, 2001, p.541). It is because, according to the Weberian idea, this origin and introduction of the theory is the hallmark of the West and colonization. It is the kind of misrepresentation that has led the West to marginalize the local knowledge (Kumaravadivelu, 2001, 2003).

The parameter of possibility has been originated from the perception of Freirean critical pedagogy which also talks about the significance of empowering learners to participate in classroom interactions. It will help them critically reflect on the social, cultural, and historical conditions contributing to create the knowledge they encounter in their lives. The experiences participants bring with them in a classroom are shaped not only by what they get to learn from their educational institutions but also by their insights received from the surrounding social, economic, and political environment. The parameter of possibility is also concerned with language ideology and learner identity (Kumaravadivelu, 2001).

\subsubsection{Indicators of Postmethod Pedagogy}

There are three major indicators of postmethod pedagogy namely the learner, the teacher, and the teacher educator. For the research purpose of this paper, the focus will be on the learner and the teacher. Initially, in 2001, he suggested three aspects of learner autonomy: social, academic, and liberatory, but in 2006, he narrowed it down into only social and academic (Chen, 2014). Similar to the teachers, the learners are also autonomous. They become autonomous by willingly taking charge of their learning after they have been equipped with cognitive, metacognitive and affective techniques by the teachers. This makes the teachers more aware of the learners' diversity and their prob- 
IJOTL TL, Vol. 5, No. 3, September 2020

p ISSN: 2502 2326; e ISSN: 2502 8278

Https://soloclcs.org; Email: ijolt1@gmail.com

Center of Language and Cultural Studies, Surakarta, Indonesia

Islam, Nazifa, Naushin. (2020). Implementation of Postmethod Pedagogy as an Alternative

to Communicative Language Teaching at the Tertiary Level Education.

IJOTL TL (2020), 5(3), 135 154. DOI: 10.30957/ijotl tl.v5i3.633.

lems. Social autonomy, on the other hand, is about the learners participating in the classroom as active members of the community. Learners not only learn themselves but also assist their peers to achieve social autonomy. The postmethod teacher is another autonomous part of this teaching and learning process. An autonomous teacher should possess such competence and confidence so that he/she can make his/her own decisions based on the learners he/she deals within a particular context (Kumaravadivelu, 2001). Kandel (2019) has also shared his thoughts about the significance of practicing learner and teacher autonomy in Nepali context. According to him, if they can avail this opportunity, it will help them reflect on their activities, progress, and achievement in terms of teaching and learning for teachers and learners respectively (p.93-95).

\subsubsection{Macrostrategies of Postmethod Pedagogy}

Kumaravadivelu has also provided some macrostrategies in order to achieve the goals of a postmethod classroom. These macrostrategies are broad guidelines to achieve autonomy in learning and teaching. There are 10 specific macrostrategies prescribed by Kumaravadivelu. The first one is maximizing learning opportunities. Here, the teacher tries to create new learning opportunities for the learners and also utilizes the learning opportunities which are originated from the learners. The second one is minimizing perceptual mismatches. The goal of this strategy is to identify the possible perceptual mismatches of goals and understanding among the teachers, learners, and teacher educators. The third one is facilitating negotiated interaction, where the learners are encouraged to initiate and continue interaction instead of just responding to their teachers. The fourth one is promoting learner autonomy. This strategy aims to equip learners in such a way that they can learn by directing and monitoring themselves. The fifth macrostrategy is fostering language awareness. This one refers to the direction to make learners aware of the properties of the form and function of the target language. The sixth one is activating intuitive heuristics. Here, the teacher has to provide the learners with enough texts to make them encounter linguistic structures so that they can internalize the rules of the target language. The seventh one is contextualizing linguistic input where the highlights are the syntactic, semantic, and pragmatic features of the target language even though the main focus here is the context. The eighth one is integrating language skills. This one involves integrating the four skills of language holistically as it is considered to be the best way to learn a language. The ninth macrostrategy is raising cultural awareness where the learners have the opportunity to differentiate between their own culture and the culture of the L2 speakers. The last macrostrategy is ensuring social relevance. Here, the teachers need to be sensitive about the social, political, economic and educational environment of the target language and consider the learners a "cultural informants" (1994, 2003).

\section{METHODS}

\subsection{Research Design}

This research has been designed following both the qualitative and quantitative methods. However, the principal focus has been given on the qualitative approach with 
IJOTL TL, Vol. 5, No. 3, September 2020

p ISSN: 2502 2326; e ISSN: 2502 8278

Https://soloclcs.org; Email: ijolt1@gmail.com

Center of Language and Cultural Studies, Surakarta, Indonesia

Islam, Nazifa, Naushin. (2020). Implementation of Postmethod Pedagogy as an Alternative

to Communicative Language Teaching at the Tertiary Level Education.

IJOTL TL (2020), 5(3), 135 154. DOI: 10.30957/ijotl t1.v5i3.633.

the use of teachers' interview and students' focus group discussion. It is because the qualitative research interviews endeavor to appreciate the world from the respondents' perspective and to explore the significance of people's experiences (Kvale, 1996). Moreover, for the quantitative approach, a questionnaire was used which is a list of questions either open-ended or close-ended for which the respondents give answers (Kabir, 2016). This small-scale survey was conducted to gather information about students' educational background as it plays a crucial role in defining and deciding the use of methods in a language classroom. While designing the research, the researcher wanted to know about the ideas, thoughts, and perceptions of both students and teachers so that the data do not represent a partial view.

\subsection{Research Participants}

As the research questions of this paper focus on both students and teachers, the researcher incorporated both of them in the research process.

\subsubsection{The Teachers}

The interviews were conducted among seven teachers of four different universities. All these teachers have the experience of teaching English language courses (e.g. ENG 101, ENG 102, ENG1001, ENG1002 etc.) for more than two years.

\subsubsection{The Students}

For the questionnaire survey, fifty students from two different universities participated. All of them were from English language courses/service courses.

In the focus group discussion, there were eight students from one university. The students were selected through random sampling, and all of them completed their three required language courses by the time they sat for the discussion.

\subsection{Research Instruments}

Three different research tools have been used to conduct this research. These three instruments are questionnaire, interview, and focus group discussion.

\subsubsection{Questionnaire for Students}

As the application and the success of both CLT and postmethod pedagogy at the tertiary level depend a lot on the educational background the students had in their school and college, a short questionnaire survey was done to know about the English classroom setting they had in their previous educational institutions. This quantitative data collection method was established on random sampling and structured data collection procedures to accommodate diverse experiences into pre-arranged categories of responses (Kabir, 2016).

\subsubsection{Interview of Teachers}

The interview was conducted in a semi-structured manner because such interviews create more scopes to adopt a flexible approach allowing the interviewer to ex- 
IJOTL TL, Vol. 5, No. 3, September 2020

p ISSN: 2502 2326; e ISSN: 2502 8278

Https://soloclcs.org; Email: ijolt1@gmail.com Center of Language and Cultural Studies, Surakarta, Indonesia

Islam, Nazifa, Naushin. (2020). Implementation of Postmethod Pedagogy as an Alternative to Communicative Language Teaching at the Tertiary Level Education. IJOTL TL (2020), 5(3), 135 154. DOI: 10.30957/ijotl tl.v5i3.633.

plore spontaneous issues raised during the interview by the interviewee. One of the significant characteristics of this interview is it lets the interviewee share his/her own stories and/or anecdotes rather than answering a bunch of pre-formatted questions (Coughlan, 2009).

\subsubsection{Teachers' Interview Questions}

1. What types of problems, constraints, or obstacles do you experience while implementing Communicative Language Teaching in your classroom?

2. How much flexibility do you enjoy while following a course outline for different language courses?

3. Do you get enough space to bring changes in course outlines/syllabus according to the needs of your students? If yes, what are the changes do you usually make? If not, why does it happen, and how do you respond to your students' needs?

4. Is it possible for you to give special care and attention to the less proficient students individually in the class? If yes, how do you do so? If not, how do you deal with such students?

5. How do you adapt the materials you use in the class to make them contextualized?

\subsubsection{Focus group Discussion of Students}

Focus group discussion is one of the vital tools for collecting qualitative data. Focus group participants share their perspectives, feeling, thought, and ideas regarding a matter in an in-detail and enriching manner. Moreover, it helps understand a precise problem from the viewpoint of the participants of any research (Dilshad\&Latif, 2013). There were seven points discussed in the focus group discussion which included themes of parameters, indicators, and macrostrategies of postmethod pedagogy.

1. The syllabus of our language classes are open-ended, and different components are added according to our needs as the course progresses.

2. The teacher gives more importance to fulfilling our needs and ensures thatwe have learnt what has been taught than focusing on finishing the syllabus.

3. In the classroom, the teacher acknowledges that not all of us possess the same capabilities, and few of us require extra attention than the others. After each lesson, the teacher addresses our feedback and later incorporates them into most lessons.

4. In the classroom, the teacher mostly uses real-life examples (such as examples from classroom, surrounding, institute, family, culture etc.) in comparison to examples from books that reflect a different culture which we are not exposed to or familiar with.

5. Whereas English is the medium of instruction, the teacher switches to Bangla sometimes if communication demands.

6. We are given the autonomy to initiate and encourage discussions by asking further questions or giving our opinion about the particular topic instead of just responding to what our teacher is asking to know. 
IJOTL TL, Vol. 5, No. 3, September 2020

p ISSN: 2502 2326; e ISSN: 2502 8278

Https://soloclcs.org; Email: ijolt1@gmail.com Center of Language and Cultural Studies, Surakarta, Indonesia

Islam, Nazifa, Naushin. (2020). Implementation of Postmethod Pedagogy as an Alternative to Communicative Language Teaching at the Tertiary Level Education. IJOTL TL (2020), 5(3), 135 154. DOI: 10.30957/ijot1 tl.v5i3.633.

7. Learning is most worthwhile for us when we become motivated enough to take charge of our own learning.

\subsection{Data Collection Procedure}

Except for one interview which was taken over the phone, all the other interviews were arranged in the teachers' respective office rooms. The researcher contacted the teachers a week before to inform them that they would be interviewed. As it was a semi-structured interview, some follow-up questions were asked based on the participants' responses. For the focus group discussion, four teachers from the researcher's department were requested to send two of their students who were already done with their service/language courses. The assigned students then met the researcher prior to the focus group discussion, and the researcher explained the procedures of the discussion. Finally, on the day of the focus group discussion, all of them came to the researcher's office room, and the discussion began; the random sampling and diversity among the participants helped the researcher comprehend students' views from different angles. The confidentiality of their opinions was assured so that they could participate and share their thoughts without any hesitation. The questionnaire survey was conducted at two different universities. The researcher did half of the survey at her own university and gave the rest of the copies of the questionnaire to one of her colleagues from a different university. She explained the questions to the participants after distributing the questionnaire among them and also requested her colleague from the other university to do the same. If students had any difficulty in understanding the questionnaire, they were allowed to ask questions to their teachers.

\subsection{Data Analysis Techniques}

This research's fundamental focus has been given on the qualitative method; however, the quantitative method has not been discarded completely. The researcher has analyzed the data collected from the interview and focus group discussion in relation with the existing literature review and research questions. As this research was designed, developed, and conducted in an Asian context, the research questions were prepared based on the researcher's experience of teaching English as a second language; thus, the literature review section has also put emphasis on the use of CLT and postmethod pedagogy in non-native speakers' English language classes. While analyzing, the researcher has intricately tried to connect the findings in search of the answers of the research questions and wanted to do a comparative analysis against the information presented on the literature review of the paper. These same steps have also been followed to analyze the questionnaire along with an additional step of converting the numerical data into percentages for the better comprehensibility.

\section{FINDINGS}

The findings of the study have been drawn from the data collected by using three different instruments. From these data, we can come to know about the challenges experienced by teachers when they try to implement CLT and postmethod pedagogy in their 
IJOTL TL, Vol. 5, No. 3, September 2020

p ISSN: 2502 2326; e ISSN: 2502 8278

Https://soloclcs.org; Email: ijolt1@gmail.com

Center of Language and Cultural Studies, Surakarta, Indonesia

Islam, Nazifa, Naushin. (2020). Implementation of Postmethod Pedagogy as an Alternative

to Communicative Language Teaching at the Tertiary Level Education.

IJOTL TL (2020), 5(3), 135 154. DOI: 10.30957/ijot1 tl.v5i3.633.

English language classrooms and also regarding the opportunities available for students which can facilitate the use of postmethod pedagogy.

4.1. Research Question 1: Difficulties experienced by English language teachers at the tertiary level while implementing CLT in language classes:

The aspects of English language classes which constrain the application of CLT at the tertiary level can be found from teachers' interview as well as from students' questionnaire. From the interview of the teachers, it is clear that classroom setting and medium of instruction are the two main reasons for this.

\section{a) Classroom setting}

Classrooms are not the haven for CLT because of having a large number of students, with approximately 35-45 students in every language class. One of the teachers specifically mentioned that she had 43 students in one of her language classes, and the seats were arranged in such a way in the small classroom that it was impossible to rearrange them for any group work. Therefore, she was bound to practice only individual and pair work in that class. For this large number of students, providing special care and individual attention to selective students becomes quite difficult. As a result, they always provide scheduled office-hours every day and also by appointment if students need additional time to discuss their problems. Another teacher added that there is no built-in sound system in any of the classrooms, and there are only two speakers in the department which again are not always available. Other teachers talked about the matter of slow or no internet connection in the classroom; moreover, sometimes air-conditions do not work properly, and there is not enough ventilation in the classrooms which influence both teachers' and students' performance negatively.

\section{b) Medium of instruction}

Another hindrance is students' reluctance in speaking in class; they do not want to interact with the teacher at all, let alone in English. Besides, learners sometimes also experience difficulties in understanding instruction in English because of the lack of exposure to the target language. However, most of the teachers opined that it is not the language but students' mindset which keeps them aloof in the class. They expect the teacher to come to the class, give a lecture the whole time, and then leave the class without asking students to participate in the class discussion, or ask them to take initiatives of own learning process.

In addition to teachers' interview, students' questionnaire also sheds light on the factors that act as obstacles to the successful execution of CLT in classes. It can be seen that majority of the students come from Bengali Medium background and they hardly get any exposure to the use of English in their school and college's English classes. Hence, the lack of basic communication skills in English makes it difficult for both the teachers and students to follow the principles of CLT at the tertiary level education. 
Table 1: Questionnaire for Students

\begin{tabular}{|c|c|c|}
\hline Questions & Options/Responses & Percentage \\
\hline a) Which medium/version are you from? & $\begin{array}{l}\text { i) Bengali Medium } \\
\text { ii) English Medium } \\
\text { iii) English Version } \\
\text { iv) Others (Please mention) }\end{array}$ & $\begin{array}{l}96 \% \\
4 \% \\
-\end{array}$ \\
\hline $\begin{array}{l}\text { b) Did your English teachers use English as a medi- } \\
\text { um of instruction in English classes in school and } \\
\text { college? }\end{array}$ & $\begin{array}{l}\text { i) Always } \\
\text { ii) Sometimes } \\
\text { iii) Never }\end{array}$ & $\begin{array}{l}8 \% \\
40 \% \\
52 \%\end{array}$ \\
\hline $\begin{array}{l}\text { c) Did you regularly get to communicate in English } \\
\text { with your English teachers in school and college? }\end{array}$ & $\begin{array}{l}\text { i) Yes } \\
\text { ii) No } \\
\text { iii) No Comment }\end{array}$ & $\begin{array}{l}12 \% \\
84 \% \\
4 \%\end{array}$ \\
\hline $\begin{array}{l}\text { d) Did you learn the basic components of spoken } \\
\text { English (how to speak in English) from the lessons } \\
\text { of your English classes in school and college? }\end{array}$ & $\begin{array}{l}\text { i) Yes } \\
\text { ii) No } \\
\text { iii) No Comment }\end{array}$ & $\begin{array}{l}16 \% \\
82 \% \\
2 \%\end{array}$ \\
\hline $\begin{array}{l}\text { e) If your answer is "No" for the previous question, } \\
\text { then do you think the absence of the practice of } \\
\text { spoken English in school and college affects your } \\
\text { class participation and presentation skills at univer- } \\
\text { sity? }\end{array}$ & $\begin{array}{l}\text { i) Yes } \\
\text { ii) No } \\
\text { iii) No Comment }\end{array}$ & $\begin{array}{l}86 \% \\
8 \% \\
6 \%\end{array}$ \\
\hline $\begin{array}{l}\text { f) If your answer is "Yes" for the previous question, } \\
\text { please explain its consequence(s). }\end{array}$ & $\begin{array}{l}\text { - feeling shy and hesitated } \\
\text {-incorrect pronunciation } \\
\text { - lacking fluency } \\
\text {-feeling scared } \\
\text { - confused between the use } \\
\text { of formal and informal } \\
\text { words and expressions } \\
\text {-not being able to answer } \\
\text {-not being able to under- } \\
\text { stand lectures }\end{array}$ & \\
\hline
\end{tabular}

It can be seen from the first question that the majority of the students, which covers $96 \%$, came from Bangla medium, and a few students consisting of a mere $4 \%$ were from English medium. While answering the second question on whether their school/college English teachers used English in giving instruction in classes, two options of 'never' and 'sometimes' received $52 \%$ and $40 \%$ respectively, and only $8 \%$ went for 'always'. In the case of the third question of the survey, a considerably large number of students which percentages in $84 \%$ opined that they did not get any opportunity to 
IJOTL TL, Vol. 5, No. 3, September 2020

p ISSN: 2502 2326; e ISSN: 2502 8278

Https://soloclcs.org; Email: ijolt1@gmail.com

Center of Language and Cultural Studies, Surakarta, Indonesia

Islam, Nazifa, Naushin. (2020). Implementation of Postmethod Pedagogy as an Alternative

to Communicative Language Teaching at the Tertiary Level Education.

IJOTL TL (2020), 5(3), 135 154. DOI: 10.30957/ijot1 tl.v5i3.633.

interact in English with their English teachers. As for the fourth question which was on learning rudimentary aspects of spoken English in school and college, $82 \%$ picked the option 'no' which is significantly higher than the percentages of 'yes' (16\%) and 'no comment' ( $2 \%)$. The fifth question was one of the follow-up questions in the questionnaire. Students who answered 'no' to the previous question were asked if the lack of the knowledge of speaking skill has any impact on their overall performance at university, such as class participation and presentation skills, and a massive $86 \%$ students picked the option 'yes'. The last question was another follow-up question to know the consequences they have to face at the university level for not getting enough exposure to the speaking and listening skills at the primary, secondary, and higher-secondary level. In response to this question, students opined how the lack of fluency, correct pronunciation, and discourse knowledge affect their confidence to participate in the classroom discussion and also revealed their struggle to understand lecturers which are delivered in English.

4.2. Research Question 2: Feasibility for teachers to attain the objectives of postmethod pedagogy at the tertiary level English language classes:

This research question aims to find out whether or not teachers have the space to practice autonomy in terms of content selection, material design, student consultation and so on in order to apply the parameters and play their roles as one of the indicators of postmethod pedagogy. Teachers' interview and students' focus group discussion inform us regarding the feasibility of using postmethod pedagogy; for example, the aspects of teachers' authority in making decisions and contextualizing materials have been found from their interview.

\section{a) Flexibility in term of making decisions}

All the teachers said that they have to follow specific pre-designed coursebook for their language classes. They have also mentioned the rigid structure of course content which is mandatory for them to follow without altering any single topic. They do not have the autonomy of changing the syllabus according to their students' competency level. In addition to this constraint, they also discussed and agreed on the point that they are always in a rush to complete the syllabus before each term or in each semester. As they do not have the freedom of customizing their course content, many a time, they have to hurriedly finish their course as all the topics need to be evaluated in the examination to maintain uniformity in the syllabus and question pattern.

However, to make the classes less militaristic, teachers often give their students the freedom of choosing the topic of a paragraph, composition, and term paper. One of the teachers said that he always asks his students to come up with topics of paragraphs and compositions which he writes down on the board, and by students' voting, the topic which receives the highest votes gets selected for their class or home task.

\section{b) Contextualization of materials}


IJOTL TL, Vol. 5, No. 3, September 2020

p ISSN: 2502 2326; e ISSN: 2502 8278

Https://soloclcs.org; Email: ijolt1@gmail.com Center of Language and Cultural Studies, Surakarta, Indonesia

Islam, Nazifa, Naushin. (2020). Implementation of Postmethod Pedagogy as an Alternative to Communicative Language Teaching at the Tertiary Level Education. IJOTL TL (2020), 5(3), 135 154. DOI: 10.30957/ijotl tl.v5i3.633.

Most of the materials used in the course book provided to the teachers are contextualized; either they are adapted after collecting them from different sources, or some of them are also written by the teachers. Again, teachers also use additional materials on their own other than the given ones for their language classes, and they always try to collect those from local sources; e.g. local newspapers, magazines, translated book etc. While answering when they use the contextualized materials, they answered that when they have to pick articles or topics for reading comprehension, response papers, summary, paraphrase, and news report, they opt for local English newspapers such as The Daily Star. Last but not least, one teacher talked about her strategy of engaging students in the process of contextualizing materials for their own use. For example, she once collected a material on the celebration of English New Year in Australia, explained it to her students, and asked them to write a similar one on the celebration of Bangla New Year in Bangladesh to use it as a passage for reading comprehension.

Along with teachers' interview, the notion of particularity parameter and teacher autonomy has appeared on the focus group discussion too. While discussing the first point of the focus group discussion, all the discussants opined that the syllabus followed in language classes are not open-ended; thus, teachers cannot bring any necessary changes according to learners' needs. The syllabus for the language courses are predesigned and the assigned reading, writing, vocabulary, and grammar items are to be finished before each term. While discussing the issue of finishing the syllabus within a given period of time, students from one university said that it is a common practice at his institute to arrange extra classes on weekends to ensure that every topic has been covered before the upcoming examination.

Furthermore, every participant from the focus group discussion agreed on the fact about the second point that their language teachers always try to incorporate examples or anecdotes from real life to make lessons more easily comprehensible for them. They also added that the materials used in classes are adapted and/or modified according to their cultural context and competency level.

4.3. Research Question 3: Scopes for students to experience the advantages of postmethod pedagogy at the tertiary level English language classes:

As the paper takes into consideration the perspectives of both the teachers and students, this question tries to discover what students think of their language learning experience. Focus group discussion was mainly arranged to find out about the parameters, indicators, and macrostrategies of postmethod pedagogy. It was not necessary for students to have knowledge about this pedagogy because the researcher tried to know about various strategies of learner autonomy from the students by asking them questions regarding their and teachers' roles in language classes.

All the participants agreed on the point that teachers always incorporate diverse components according to students' needs and wants. If they want to know or learn something which is not a part of the course, their teachers always encourage this idea and provide additional materials and/or website links in class; moreover, if teachers cannot manage time in class for such content, students are allowed to go to their teach- 
IJOTL TL, Vol. 5, No. 3, September 2020

p ISSN: 2502 2326; e ISSN: 2502 8278

Https://soloclcs.org; Email: ijolt1@gmail.com Center of Language and Cultural Studies, Surakarta, Indonesia

Islam, Nazifa, Naushin. (2020). Implementation of Postmethod Pedagogy as an Alternative to Communicative Language Teaching at the Tertiary Level Education. IJOTL TL (2020), 5(3), 135 154. DOI: 10.30957/ijotl tl.v5i3.633.

ers during office hours. On the same note, they have also said that they can go and meet their teachers during consultation hours if they do not understand anything in the class, and teachers always create a non-discriminatory environment in classrooms to ensure that learning is comfortable and convenient for all. Nevertheless, one of the students had a completely opposite notion of meeting a teacher outside of the classroom because when he went to meet a certain teacher at the time of his assigned office hour, the student was rebuked harshly for not asking the question in class. This student also added that the teacher never likes it when students go for consultations and suggests to the students that either they should clarify all their confusions in class or by themselves.

About the medium of instruction, six students opined that their teachers follow a strict English medium instruction policy in classes, and two students told that their teachers use and also allow them to use their L1 from time to time to clarify the core issues of any lessons, however, in a very minimal level.

All the students from the FGD opined that their teachers provide them with enough space and opportunity for asking questions and interacting with him/her. They had also added that a few of their teachers also ask their opinion when it comes to choosing a topic for a paragraph or composition, and before starting the class, teachers always ask them different questions to find out their background knowledge regarding the topic. One of the students said that when his topic was chosen for class discussion by the teachers, he felt confident and proud.

Almost all of them agreed that their teachers never get agitated if they ask a lot of questions in class, and it is not only with the teacher but also the peers can have an open discussion on a selected topic. Furthermore, they also get to practice pair work and group work for various lessons. In addition to that, they sometimes check their own and their classmates' copies using the correction symbols provided by the course instructor. However, one student said that she had more opportunities to share her ideas and opinions, and to take part in group works in her ENG102 course than in ENG101, as there were almost forty-five students in the latter course which made it nearly impossible for the teacher to design lesson plans and conduct classes accordingly.

\section{DISCUSSIONS}

5.1. Difficulties experienced by English language teachers at the tertiary level while implementing CLT in language classes:

Students' responses to the questionnaire provide us with some of the obvious causes of their impairments in using communicative English at the university level.Bangla medium, English medium, and English version are the three most common educational background in Bangladesh. Bangla medium and English version cover the same syllabus, textbooks, and board examinations (SSC and HSC); the only difference is the textbooks of the English version are written in English. On the other hand, English medium has entirely different syllabus and textbooks, and the examinations (Olevel and A-level) are also not conducted under local examination boards. It is the students from Bangla medium who get the minimum exposure to spoken English as our school/college teachers also prefer to use Bangla in the English classes. Moreover, for 
IJOTL TL, Vol. 5, No. 3, September 2020

p ISSN: 2502 2326; e ISSN: 2502 8278

Https://soloclcs.org; Email: ijolt1@gmail.com

Center of Language and Cultural Studies, Surakarta, Indonesia

Islam, Nazifa, Naushin. (2020). Implementation of Postmethod Pedagogy as an Alternative

to Communicative Language Teaching at the Tertiary Level Education.

IJOTL TL (2020), 5(3), 135 154. DOI: 10.30957/ijot1 t1.v5i3.633.

the frequent use of GTM in classrooms, reading and writing get the highest priority in such contexts (Ghenbari\&Ketabi, 2011).

In resonance with this problem, our students also do not have opportunities to communicate with their teachers which hinders their development of the communicative and pragmatic use of the L2. Islam (2000). Liao (2004), and Huda (2013) argued in their individual articles that how the hierarchical boundary drawn between students and teachers make the learners suffer to a great extent because of the absence of their mutual understanding and conversation. As a result, our learners at the university level cannot initiate a conversation but can only respond to teachers; they lack the expertise in guiding and monitoring themselves and a thorough understanding of forms and functions of L2. They also cannot internalize the properties of the target language and most importantly, fail to integrate all four skills of their second language (Kumaravadivelu, 1994, 2003).

Not only from the questionnaire but also from teachers' interview, it is quite clear that there are several difficulties in implementing CLT in their language classes. Unlike our schools and colleges, it is not anymore because of the scarcity of contextual and/or appropriate materials, but because of the infrastructural issues and the academic culture prevalent in our country. Firstly, there are limited resources in language classrooms to deal with a huge number of students, and the top-down authoritarian approach followed in the institutions exacerbates the situation. We can find the similar inadequacies discussed by Gahin and Mayhill (2001) in their article. Secondly, our students have the low intrinsic motivation to communicate in the target language; as a result, they feel reluctant and demotivated while interacting in classes with their teachers as well as among themselves. As it has been argued by Koosha and Yakhabi in their article that if English is not considered as an indispensable part of their everyday life, they only aim for passing the examination or getting a job instead of realizing its importance for regular communicative purposes; the extrinsic motivation weighs more here than the intrinsic one. Without an obvious and established need or goal, students lack the motivation to speak in English (2013).

However, we cannot blame our students for their disinclination as they have been heavily influenced by their previous examination pattern and classroom experience. The washback effect, the impact of a test on teaching and learning of their Secondary School Certificate (SSC) and Higher Secondary Certificate (HSC) examinations, makes them dependable on the reading and writing skills of English without putting any emphasis on the speaking and listening skills. The board examinations test students' rote learning capability and their competencies in vocabulary and grammar. Thus, the school and college teachers cannot help but follow GTM in their lessons to help students pass the examinations. Ghanbari and Ketabi have shared their perception of how the structure of such examination has catastrophic effects on the CLT English course at universities (2011).

5.2. Feasibility for teachers to attain the objectives of postmethod pedagogy at the tertiary level English language classes: 
IJOTL TL, Vol. 5, No. 3, September 2020

p ISSN: 2502 2326; e ISSN: 2502 8278

Https://soloclcs.org; Email: ijolt1@gmail.com Center of Language and Cultural Studies, Surakarta, Indonesia

Islam, Nazifa, Naushin. (2020). Implementation of Postmethod Pedagogy as an Alternative to Communicative Language Teaching at the Tertiary Level Education. IJOTL TL (2020), 5(3), 135 154. DOI: 10.30957/ijotl tl.v5i3.633.

Because of the above-mentioned impairments found in CLT and other methods, Kumaravadivelu pioneered the postmethod pedagogy. The parameters, indicators, and strategic frameworks of this pedagogy discussed in the literature review show how he wanted to safeguard learner and teacher autonomy by ensuring the practice of particularity, practicality, and possibility to achieve context-specific and need-based macrostrategies (Kumaravadivelu, 2001). Nevertheless, like CLT, postmethod pedagogy has also failed to thrive in Bangladeshi tertiary level of education. If we analyze teachers' interview, it is evident that teachers and students cannot practice autonomy in the academia. None of them can bring changes in the syllabus, materials, and mark distribution according to any particular needs and demands of classroom situation as uniformity is strictly followed for the language courses. Their theoretical knowledge of needs analysis and target situation analysis never get to see the light of day, therefore, remains a vast discrepancy between learning the theories and implementing them in authentic classroom settings.

As a result, it can be said that the parameter of particularity which deals with tailoring language pedagogy to make it work for particular teachers teaching particular students in a particular context to pursue a particular set of goals, and the parameter of practicality that amalgamates the learning and practicing of theories are ominously absent in our ESL context as our teachers do not enjoy the choice and space to make decisions on their own. On the same note, Islam (2000) and Huda (2013) have opined how the academic practices of Bangladeshi schools and colleges negatively influence learner autonomy when they enter the tertiary educational sphere. As for possibility, to some extent, it is practiced by the teachers because they have opined in the interview that they try to minimize the potential mismatch between what their students experience out of the classroom and what they learn in the classrooms. They have elucidated it with an example of how they give their students the freedom to primarily choose their term paper or composition topics which they can relate to their individual society, ethnicity, and surrounding. It is important to prioritize students' background, upbringing, and schemata as the knowledge learners bring to classrooms is often shaped by the broader cultural, socio-economic and political environment in which they grow up (Kumaravadivelu, 2003).

In line with the teachers' interview, similar finding can be found in students' FGD regarding the rigidity in changing the syllabus. As teachers do not have the leverage to bring changes in the syllabus according to their learners' needs, it hinders maximization of learning opportunities which also refrains teachers in achieving the parameter of particularity as it is beyond their control to consider any particular needs of their learners (Kumaravadivelu, 2001).

5.3. Scopes for students to experience the advantages of postmethod pedagogy at the tertiary level English language classes:

Though teachers cannot focus on every student in class because of the time constraint and a large number of students, they provide the extra time or consultation hours to assist learners in their language learning and also in their further queries. It paves the 
IJOTL TL, Vol. 5, No. 3, September 2020

p ISSN: 2502 2326; e ISSN: 2502 8278

Https://soloclcs.org; Email: ijolt1@gmail.com

Center of Language and Cultural Studies, Surakarta, Indonesia

Islam, Nazifa, Naushin. (2020). Implementation of Postmethod Pedagogy as an Alternative

to Communicative Language Teaching at the Tertiary Level Education.

IJOTL TL (2020), 5(3), 135 154. DOI: 10.30957/ijotl t1.v5i3.633.

way of fostering language awareness and activating intuitive heuristics because learners get the opportunities of learning and discussing different properties of their L2 learning outside of the classroom to improve their linguistic and communication skills.

Moreover, within limitations, the teachers try to practice particularity and possibility by using contextualized materials in class and giving examples and anecdotes which can ensure social and cultural relevance (Kumaravadivelu, 2003). When students are allowed to use Bangla from time to time in classes to facilitate the second language learning process, it definitely helps reduce perceptual mismatches between teachers and learners.

At the same time, teachers also encourage students to choose the topics and show respect to learners' choice and point of view by allowing them to share their personal perspectives with teachers and also among themselves; they also get to provide peer feedback to their classmates. Thus, these initiatives can be considered as pragmatic implementations of the practicality parameter that makes teachers practice the theoretical notion of learner autonomy in real-life language classes (Kumaravadivelu, 2001; Kumaravadivelu, 2003).

The following table shows the discrete as well as fundamental limitations found in both CLT and postmethod pedagogy in Bangladeshi context.

Table 2: Common and Discrete Challenges in the Use of CLT and Postmethod Pedagogy

\begin{tabular}{|c|c|c|}
\hline $\begin{array}{c}\text { Communicative Language } \\
\text { Teaching } \\
\text { (CLT) }\end{array}$ & $\begin{array}{c}\text { Common Core Problems } \\
\text { (Both CLT \& PMP) }\end{array}$ & $\begin{array}{c}\text { Postmethod Pedagogy } \\
\text { (PMP) }\end{array}$ \\
\hline 1. large classroom size & 1. social settings & 1. top-down approach \\
\hline 2. lack of exposure & 2. fossilized mindset & $\begin{array}{c}\text { 2. absence of teacher and learner au- } \\
\text { tonomy }\end{array}$ \\
\hline 3. students' reluctance & 3. absence of creativity & 3. time constraint \\
\hline
\end{tabular}

Nowadays, creativity, versatility, innovation, and autonomy seem to dominate the academia by thinking outside the box and by not following pre-fabricated approaches and strategies decided by the non-native theorists and practitioners (Didenko\&Pichugova, 2016). As a result, our teachers have also decided to follow posetmethod pedagogy which can allow and enable themselves and their learners to decide what is appropriate for them according to their teaching context and cultural practices of the society and community (Huda, 2013). In practice, the reality is quite disappointing for both the parties, and various restrictions and limitations found in the social and academicsettingsare mostly responsible for it.

\section{CONCLUSION \& RECOMMENDATIONS 6.1 Conclusion}

Based on the above discussion, it is clear that for different reasons, CLT cannot achieve its principles and objectives in English language classes of Bangladeshi university, and Bangladesh is not the only country to face these challenges. As a result, by following the footsteps of other non-native speakers' countries, Bangladeshi tertiary level 
IJOTL TL, Vol. 5, No. 3, September 2020

p ISSN: 2502 2326; e ISSN: 2502 8278

Https://soloclcs.org; Email: ijolt1@gmail.com

Center of Language and Cultural Studies, Surakarta, Indonesia

Islam, Nazifa, Naushin. (2020). Implementation of Postmethod Pedagogy as an Alternative

to Communicative Language Teaching at the Tertiary Level Education.

IJOTL TL (2020), 5(3), 135 154. DOI: 10.30957/ijot1 tl.v5i3.633.

teachers are also trying to implement postmethod pedagogy as an alternative to liberate themselves and their students from the shackles of CLT. However, the context is not in their favor because they have to experience a number of hurdles for achieving the objectives of postmethod pedagogy.

The researcher found in students' focus group discussion that how their teachers try to empower the learners and adapt the materials according to their needs and cultural background; however, it has been noticed in both teachers' and students' opinion that teachers do not have the freedom to alter or adapt the syllabus, question pattern, and mark distribution according to the target situation analysis as every language teacher is instructed to follow uniformity when it comes to these aspects of a language course. Consequently, the two indicators, teachers and students, in our country can only get to practice the parameters of particularity, practicality, and possibility with some restrictions which make them question their anticipated success and achievement in implementing the macrostrategies productively in their teaching.

\subsection{Recommendations}

Therefore, the spheres we have to work on to accomplish a more autonomous, congenial, and effective teaching and learning environment are:

- minimizing the number of students in language classes

- reducing the practice of bureaucratic and hierarchical approaches in academia

- adapting course outlines and lesson plans based on students' performance

- providing teachers with enough freedom to incorporate, design, adapt, and evaluate teaching components according to students' needs

- focusing on fulfilling students' needs instead of completing the syllabus

The future researches can be conducted on these above-mentioned criteria to investigate how much advancement has been made for the consequential implementation of postmethod pedagogy in Bangladeshi context.

\section{REFERENCES}

Chen, M. (2014). Postmethod Pedagogy and Its Influence on EFL Teaching Strategies. English Language Teaching, 7, 17-25. doi:10.5539/elt.v7n5p17

Coughlan, M. (2009). Interviewing in qualitative research. International Journal of Therapy and Rehabilitation, 16, 309-314. DOI: 10.12968/ijtr.2009.16.6.42433

Didenko, A.V. \& Pichugova, I.L. (2016). Post CLT or Post-Method: major criticisms of the communicative approach and the definition of the current pedagogy. SHS Web of Conferences, 28, 1-4. Retrieved from https://www.shsconferences.org/articles/shsconf/pdf/2016/06/shsconf_rptss2016_01028.pdf

Dilshad, R. M. \& Latif, M. I. (2013). Focus Group Interview as a Tool for Qualitative Research: An Analysis. Pakistan Journal of Social Sciences (PJSS), 33, 191198. Retrieved from https://www.bzu.edu.pk/PJSS/Vol33No12013/PJSS-Vol33No1-16.pdf 
IJOTL TL, Vol. 5, No. 3, September 2020

p ISSN: 2502 2326; e ISSN: 2502 8278

Https://soloclcs.org; Email: ijolt1@gmail.com

Center of Language and Cultural Studies, Surakarta, Indonesia

Islam, Nazifa, Naushin. (2020). Implementation of Postmethod Pedagogy as an Alternative

to Communicative Language Teaching at the Tertiary Level Education.

IJOTL TL (2020), 5(3), 135 154. DOI: 10.30957/ijotl t1.v5i3.633.

Gahin, G., \& Myhill, D. (2001) The Communicative Approach in Egypt: Exploring the Secrets of the Pyramids. TEFL Journal, 1, 72-81. Retrieved from http://www.teflwebj.org/v1n2/Gahin_Myhill.html

Ghanbari, B, \& Ketabi, S. (2011). Practicing a Change in an Iranian EFL Curriculum: from Ivory Tower to Reality. Iranian EFL Journal, 7, 9-13. Retrieved from https://www.mjselt.com/wp-content/uploads/2014/01/Decembert-2011-Vol76.pdf

Huda, E. M. (2013). Post-Method Pedagogy and ELT in Bangladesh. Global Journal of Human Social Sciences, 13 (7), 7-14. Retrieved from https://globaljournals.org/GJHSS_Volume13/2-Post-Method-Pedagogy-andELT.pdf

Kabir, S. M. S. (2016). Basic Guidelines for Research. Chittagong: Book Zone Publication.

Kandel, R. K. (2019). Postmethod Pedagogy in Teaching English as a Foreign Language: Students' Perceptions. Journal of NELTA Gandaki (JoNG), 2, 91-112. Retrieved from https://www.scilit.net/article/d9b61d326c736f1c0207c19b329642d6

Koosha, M. \& Yakhabi, M. (2013). Problems Associated with the Use of Communicative Language Teaching in EFL Contexts and Possible Solutions. International Journal of Foreign Language Teaching \& Research, 1, 77-90. Retrieved from https://pdfs.semanticscholar.org/76c5/454d0d3931e773be58e3804e1e13081ea4d c.pdf

Kumaravadivelu, B. (1994). The postmethod condition: Emerging strategies for second/foreign language teaching. TESOL Quarterly, 28, 27-48. DOI: $10.2307 / 3587197$

Kumaravadivelu, B. (2001). Toward a Postmethod Pedagogy. TESOL Quarterly, 35, 537-560. Retrieved from http://www.bkumaravadivelu.com/articles\%20in\%20pdfs/2001\%20Kumaravadi velu\%20Postmethod\%20Pedagogy.pdf

Kumaravadivelu, B. (2003). Beyond Methods: Macrostrategies for Language Teaching. New Haven and London: Yale University Press.

Kvale, S. (1996). Interviews: An introduction to qualitative research interviewing. Thousand Oaks, CA: Sage.

Li, D. (1998). It's always more difficult than you plan and imagine: Teachers' perceived difficulties in introducing the communicative approach in South Korea. TESOL Quarterly, 32, 677-703. DOI: 10.2307/3588000

Liao, X. (2014). The need for Communicative Language Teaching in China. ELT Journal, 58, 270-273. DOI: 10.1093/elt/58.3.270

Lightbown, P.M., \& Spada N. (1999). How Languages are Learned. Oxford: Oxford University Press.

Nunan, D. (2003). Practical English Language Teaching. New York: McGraw Hill

Pennycook, A. (1989). The concept of method, interested knowledge, and the politics of language teaching. TESOL Quarterly, 23, 589-618. DOI: 10.2307/3587534 
IJOTL TL, Vol. 5, No. 3, September 2020

p ISSN: 2502 2326; e ISSN: 2502 8278

Https://soloclcs.org; Email: ijolt1@gmail.com

Center of Language and Cultural Studies, Surakarta, Indonesia

Islam, Nazifa, Naushin. (2020). Implementation of Postmethod Pedagogy as an Alternative

to Communicative Language Teaching at the Tertiary Level Education.

IJOTL TL (2020), 5(3), 135 154. DOI: 10.30957/ijotl tl.v5i3.633.

Richards, J. C. \& Rodgers, T. S. (2001). Approaches and methods in language teaching (2nd ed.). New York: Cambridge University Press.

Stern, H.H. (1983). Fundamental Concepts of Language Teaching. Oxford: Oxford University Press. 
IJOTL TL, Vol. 5, No. 3, September 2020

p ISSN: 2502 2326; e ISSN: 2502 8278

Https://soloclcs.org; Email: ijolt1@gmail.com

Center of Language and Cultural Studies, Surakarta, Indonesia

Islam, Nazifa, Naushin. (2020). Implementation of Postmethod Pedagogy as an Alternative

to Communicative Language Teaching at the Tertiary Level Education.

IJOTL TL (2020), 5(3), 135 154. DOI: 10.30957/ijotl tl.v5i3.633. 